JURNAL

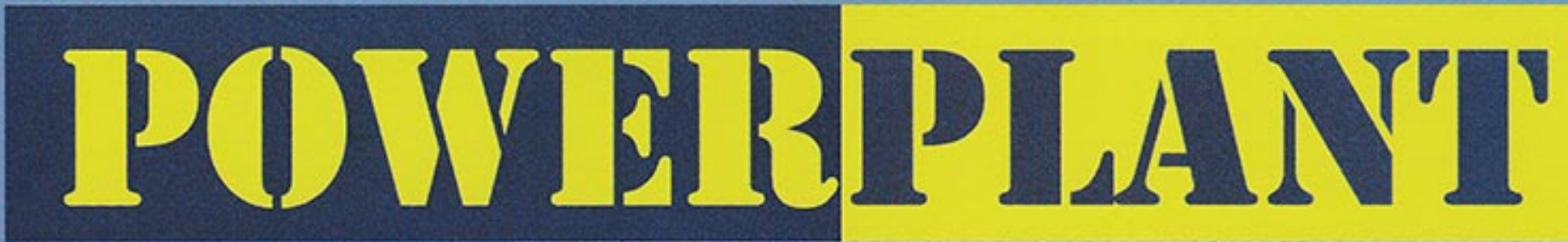

Roswati Nurhasanah

Jasmid Edy

Eza Brian Pradana

\section{Arief Suardi}

Vendy Antono

Al Asyi

Arisma Chairul Syarif Iman Kartolaksono R Jalu Eko Harjono

Nofirman

Yusuf Rasyid

Win Alfalah

Eko Sulistyo

Rahmat Ikhsan

Utami Wahyuningsih

Halim Rusjdi

Eko Sulistiyo

Sahlan

Jumiati

Intan Ratna Sari Yanti

Sri Yayi
Perancangan Boiler Dengan Memanfaatkan Sampah

Kering Untuk Bahan Bakar PLTU Mini 3 kW STT-PLN

Analisis Perbandingan Penggunaan Big Oil Gun dan Tiny Oil Gun terhadap Kosumsi Bahan Bakar Pada Saat Strat Up Unit di PLTU Banten Lontar

Uji Prestasi dan Emisi Diesel Berbahan Bakar Minyak Nabati Murni untuk Pembangkitan Daya di Daerah Terpencil

Pengukuran Suhu Pembakaran di Dalam Boiler : Pirometer Akuistik VS Pirometer Infared

Pengaruh Pemeliharaan Overhoul Turbo Charger

Terhadap Kinerja Mesin Unit VII PLTD Ampenan

Penanggulangan Korosi Pada Pipa Gas Dengan Metode Catodic Protection (Anoda Karbon) PT PGN Solution Area Cengkareng

Analisis Strategi Teknologi PLTS Fotovoltik di Indonesia Terhadap Nilai Eqivalensi dan Pemanfatan Per Wilayah

Pengembangan Model Pembelajaran Berbasis Tutorial Bagi Mahasiswa Teknik Mesin STT PLN

\begin{tabular}{|c|c|c|c|c|c|c|}
\hline 111 & & $\mathrm{SE}$ & OLAH & INGGI TEY & PLN (STT-PLN) & \\
\hline$\||\|||| \mid$ & JURNAL POWERPLANT & VOL. 5 & NO. 1 & HAL. 1.63 & NOVEMBER 2017 & ISSN No :2356-1513 \\
\hline
\end{tabular}




\title{
ANALISIS STRATEGI TEKNOLOGI PLTS FOTOVOLTAIK DI INDONESIA TERHADAP NILAI EQIVALENSI DAN PEMANFAATAN PERWILAYAH
}

\author{
Sahlan \\ Program S1 Teknik Mesin, STT-PLN \\ sahlan_1956@yahoo,com
}

\begin{abstract}
Abstrak
Nilai eqivalensi dan pemanfaatan perwilayah dalam fokus Analisis Strategi Teknologi PLTS Fotovoltaik di Indonesia adalah suatu bentuk analisis optimasi potensi enersi PLTS berdasarkan hasil keluaran model MARKAL dengan mengambil dua kasus yaitu kasus dasar (BASE CASE) dan kasus biaya investasi PLTS bervariasi (PVCOST). Kasus dasar merupakan kasus dimana semua kondisi diambil berdasarkan kondisi tahun 2000 hingga tahun 2016. apabila pertumbuhan konsumsi tenaga listrik rata-rata diasumsikan tetap, pada tahun 2030 Jawa diperkirakan membutuhkan PLTS sebesar 12,16 GW. Akan tetapi pemanfaatan PLTS sebesar 12,16 GW pada kasus dasar dan 46,65 GW pada kasus PVCOST di Jawa dan 16,85 GW pada kasus PVCOST di Sumatra dapat dikatakan tidak rasional mengingat masih ada sumber energi setempat yang dapat dimanfaatkan seperti mini/mikrohidro dan panas bumi yang belum dimanfaatkan secara optimal.
\end{abstract}

\begin{abstract}
The equivalence value and utilization by region in the focus of the Technology Strategy Analysis Photovoltaic solar power in Indonesia is a form of solar power energy potential optimization analysis based on the results of the model output MARKAL by taking two cases: the base case (BASE CASE) and the case of investment costs vary PLTS (PVCOST). The base case is a case where all conditions are taken based on the conditions from 2000 to 2016 when growth in electricity consumption is assumed to remain average, in 2030 Java is expected to require PLTS of $12.16 \mathrm{GW}$. But the use of solar power at $12.16 \mathrm{GW}$ by-case basis and $46.65 \mathrm{GW}$ in the case PVCOST in Java and $16.85 \mathrm{GW}$ in the case PVCOST in Sumatra can be said to be irrational considering there are still local energy sources that can be used like a mini/micro-hydro and geothermal has not been used optimally.
\end{abstract}

Kata Kunci: Strategi Teknologi, Nilai Eqivalensi, model MARKAL

\section{Pendahuluan}

Indonesia memiliki banyak potensi energi terbarukan, seperti tenaga air (termasuk minihidro), panas bumi, biomasa, angin dan surya (matahari) yang bersih dan ramah lingkungan, tetapi pemanfaatannya belum optimal. Belum optimalnya pemanfaatan energi terbarukan disebabkan biaya pembangkitan pembangkit listrik energi terbarukan, seperti tenaga surya, tidak dapat bersaing dengan biaya pembangkitan pembangkit listrik berbahan bakar energi fosil (bahan bakar minyak, gas bumi, dan batubara).

Indonesia terletak di garis katulistiwa, sehingga Indonesia mempunyai sumber energi surya yang berlimpah dengan intensitas radiasi matahari rata-rata sekitar $4.8 \mathrm{kWh} / \mathrm{m} 2$ per hari di seluruh wilayah Indonesia. Dengan berlimpahnya sumber energi surya yang belum dimanfaatkan secara optimal, sedangkan di sisi lain ada sebagian wilayah Indonesia yang belum terlistriki karena tidak terjangkau oleh jaringan listrik PLN, sehingga Pembangkit Listrik Tenaga Surya (PLTS) dengan sistemnya yang modular dan mudah dipindahkan merupakan salah satu solusi yang dapat dipertimbangkan sebagai salah satu pembangkit listrik alternatif. Sayangnya biaya pembangkitan PLTS masih lebih mahal apabila dibandingkan dengan biaya pembangkitan pembangkit listrik tenaga konvensional, karena sampai saat ini piranti utama untuk mengkonversi energi matahari menjadi energi listrik (modul fotovoltaik) masih merupakan piranti yang didatangkan dari luar negeri.

Walaupun pemanfaatan PLTS belum optimal, tetapi sudah cukup banyak 
dimanfaatkan pada perumahan atau sering disebut Solar Home System (SHS), pompa air, televisi, komunikasi, dan lemari pendingin di PUSKESMAS di beberapa wilayah Indonesia, khususnya di wilayah terpencil yang jauh dari jaringan listrik PLN. PLTS merupakan teknologi yang ramah lingkungan karena tidak melepaskan polutan seperti halnya pembangkitan listrik berbahan bakar fosil.

Kementerian Energi dan Sumber Daya Mineral telah menetapkan Peraturan Menteri ESDM No. 19 Tahun 2016 tentang Pemberlian Tenaga Listrik dari Pembangkit LIstrik Tenaga Surya Fotovoltaik oleh PT. PLN. Dalam peraturan tersebut mengatur Penugasan Pembelian Tenaga Listrik dari PLTS Fotovoltaik kepada PT. PLN (Persero), Ketentuan Penggunaan Barang dan/atau Jasa Dalam Negeri dalam Pembangunan PLTS Fotovoltaik dan Standar PLTS Fotovoltaik, Harga Pembelian Tenaga Listri dari PLTS Fotovoltaik dan Kuota Kapasitas serta Pelaksanaan Pembelian Tenaga Listrik dari PLTS Fotovoltaik.

Untuk mendapatkan gambaran potensi penerapan PLTS di Indonesia terhadap kendala penerapan PLTS di Indonesia dengan mempertimbangkan berbagai variasi biaya investasi, dilakukan penelitian mengenai "Analisis Potensi Pembangkit Listrik Tenaga Surya di Indonesia”. Penelitian ini dilakukan dengan menggunakan perangkat lunak dan biaya investasi PLTS yang bervariasi. Hasil penelitian ini dapat digunakan sebagai acuan dalam menentukan pembangkit listrik alternatif terutama di daerah terpencil.

\section{Analisis Eqivalensi Strategi Teknologi PLTS}

Strategi Teknologi dengan analisis eqivalensi Potensi PLTS dianalisis berdasarkan hasil keluaran model MARKAL dengan mengambil dua kasus yaitu kasus dasar (BASE CASE) dan kasus biaya investasi PLTS bervariasi (PVCOST). Kasus dasar merupakan kasus dimana semua kondisi diambil berdasarkan kondisi tahun 2000. Sedangkan pada kasus biaya investasi PLTS bervariasi, biaya investasi PLTS diasumsikan berdasarkan pada penelitian Amerika Serikat, dimana pada penelitian tersebut biaya investasi PLTS dimasa mendatang diperkirakan akan terus menurun.

Asumsi yang diperkirakan sama pada kedua kasus tersebut adalah harga minyak mentah sebesar 28 US\$/barrel, kapasitas pelabuhan penerima batubara di Pulau Jawa terbatas, pertumbuhan tenaga listrik sebesar $7 \%$ per tahun, biaya operasi dan pemeliharaan tetap (FIXOM) sebesar 1\% dari biaya investasi, dan kurun waktu penelitian mulai tahun 2000 sampai dengan 2030.

Asumsi yang berbeda dari kedua kasus tersebut adalah biaya investasi PLTS. Biaya investasi PLTS pada kasus dasar diasumsikan sebesar 5.830 US\$/kW pada tahun 2000, 3.190 US\$/kW pada tahun 2005, dan 1.650 US\$/kW pada tahun 2010 sampai akhir periode. Sedangkan biaya investasi PLTS pada kasus PVCOST pada tahun 2000, 2005, dan 2010 diasumsikan sama dengan kasus dasar yaitu $1.650 \mathrm{US} \$ \mathrm{~kW}$, kemudian biaya investasi ini menurun menjadi 1.430 US $\$ \mathrm{~kW}$ pada tahun 2015, 1.210 US\$/kW pada tahun 2020, 1.089 US $\$ / \mathrm{kW}$ pada tahun 2025, dan 968 US $\$ / \mathrm{kW}$ pada tahun 2030.

Optimisasi potensi PLTS dengan menggunakan model MARKAL pada kedua kasus tersebut, dipertimbangkan berdasarkan biaya sistem penyediaan energi yang rendah dan dampak penggunaan energi terhadap lingkungan yang minimal. Hasil keluaran model MARKAL yang diperlukan untuk menganalisis perbedaan potensi PLTS di Indonesia pada kasus dasar dan PVCOST adalah kapasitas dan produksi listrik dari PLTS, total system cost, dan total emisi CO2.

Analisis Potensi Energi Surya Indonesia mempunyai intensitas radiasi yang berpotensi untuk membangkitkan energi listrik, dengan rata-rata daya radiasi matahari di Indonesia sebesar $1000 \mathrm{Watt} / \mathrm{m} 2$.

Nusa Tenggara Barat dan Papua mempunyai intensitas radiasi matahari paling tinggi di seluruh wilayah Indonesia, sedangkan Bogor mempunyai intensitas radiasi matahari paling rendah di seluruh wilayah Indonesia. Dalam penelitian potensi PLTS di Indonesia ini, semua wilayah baik yang mempunyai intensitas radiasi matahari paling tinggi maupun paling rendah dipertimbangkan.

Secara umum biaya pembangkitan PLTS lebih mahal dibandingkan dengan biaya pembangkitan pembangkit listrik tenaga fosil, pembangkit listrik tenaga air, minihidro, dan panas bumi. Tetapi seiring dengan adanya penelitian dari Amerika yang menyatakan bahwa biaya investasi PLTS di masa datang akan menurun, sehingga dengan dihapuskannya subsidi Bahan Bakar Minyak (BBM) secara 
bertahap dimungkinkan PLTS dapat dipertimbangkan sebagai pembangkit listrik alternatif.

Pada tahun 2002, masih banyak daerah terpencil dan pedesaan yang tidak dilewati jaringan listrik PLN, sehingga hanya pembangkit listrik tenaga diesel (PLTD) yang dimanfaatkan di daerah tersebut. Dengan makin sulitnya memperoleh kesinambungan pasokan minyak solar, menyebabkan beberapa wilayah di Indonesia memanfaatkan PLTS untuk subsitusi PLTD. Pemanfaatan PLTS khusus untuk daerah pedesaan yang kebutuhan listriknya rendah, mengingat di daerah ini listrik diutamakan untuk penerangan. Selain untuk penerangan ada beberapa wilayah yang memanfaatkan PLTS sebagai sumberdaya listrik untuk telekomunikasi, lampu suar, lemari pendingin (Puskesmas), dan pompa air. Pada tahun tersebut, total kapasitas terpasang PLTS di wilayah Indonesia hampir mencapai 3 MWp.

\section{Analisis Pemanfaatan PLTS per Wilayah}

Dalam Strategi Teknologi yang terkait dengan regulasi Peraturan Menteri ESDM No. 19 Tahun 2016 tentang Pemberlian Tenaga Listrik dari Pembangkit LIstrik Tenaga Surya Fotovoltaik oleh PT. PLN maka secara hitungan diatas kertas dapat terealisasi. Dari analisis data diatas, pada tahun 2002 total kapasitas terpasang PLTS di wilayah Indonesia hampir mencapai 3 MWp, seiring dengan adanya Bantuan Presiden (melalui BPPT) pada tahun 1996 tentang pemanfaatan PLTS di 15 provinsi di Indonesia, khususnya di wilayah-wilayah terpencil yang sulit dijangkau oleh jaringan distribusi listrik nasional (PLN) dengan kapasitas 50 Wp per rumah tangga dengan total unit sebanyak 3.430. Selanjutnya, pemerintah mencetuskan Program Listrik Sejuta Rumah, khususnya untuk 9 provinsi di Kawasan Timur Indonesia yang sampai saat ini telah terpasang sebanyak 37.800 unit. Kemudian ditambah dengan kapasitas terpasang PLTS yang diterapkan melalui DJLPE, Pemerintah Daerah, Departemen Kesehatan, dan Badan Pemerintah lainnya. Sayangnya pemanfaatan PLTS ini tidak dapat berkembang, bahkan sebagian PLTS yang terpasang telah rusak dan belum diperbaiki karena banyak mengalami kendala teknis dan ekonomi seperti tingginya biaya investasi dan perawatan.
Sejalan dengan penurunan biaya investasi PLTS seperti prospek pemanfaatan PLTS di kemudian hari akan semakin terbuka, terutama di daerah yang pasokan listriknya terbatas dan tidak terjangkau listrik PLN. Perkiraan kapasitas dan produksi listrik PLTS di beberapa wilayah pada kasus dasar dan kasus penurunan biaya investasi PLTS ditunjukkan pada Tabel 1.

Tabel 1: Kapasitas Dan Produksi Listrik PLTS pada Kasus Dasar dan PVCOST

\begin{tabular}{|c|c|c|c|c|c|c|c|}
\hline \multirow{2}{*}{$\begin{array}{l}\text { Jenis } \\
\text { Energi }\end{array}$} & \multicolumn{7}{|c|}{ Rata-Rata pertahun (\%/th) } \\
\hline & 94:99 & 999-04 & 04-09 & 09:"14 & 14:19 & 19-'24 & 24:29 \\
\hline Batubara & 25,230 & 40,757 & 40,218 & 44,309 & 60,326 & 72,343 & 77,347 \\
\hline Diesel & 19,131 & 10,084 & 7,660 & 5,906 & 0,751 & 0,798 & 0,653 \\
\hline Minyak Bakar & 12,778 & 0,946 & 0,000 & 0,540 & 0,000 & 0,000 & 0,000 \\
\hline Gas Bumi & 24,851 & 22,805 & 25,619 & 20,802 & 15,077 & 10,000 & 8,422 \\
\hline Panas Bumi & 2,543 & 2,584 & 2,210 & 1,767 & 1,321 & 0,270 & 0,000 \\
\hline Tenaga Air & 13,922 & 21,469 & 23,169 & 25,795 & 21,858 & 16,237 & 13,291 \\
\hline Biomasa & 1,544 & 1,354 & 1,124 & 0,881 & 0,668 & 0,351 & 0,286 \\
\hline
\end{tabular}

Sesuai hasil model MARKAL dengan biaya investasi sebesar $1.650 \mathrm{US} \$ / \mathrm{kW}$, pada tahun 2010 Nusa Tenggara sudah dapat memanfaatkan PLTS untuk memenuhi kebutuhan listriknya, pada tahun 2015 selain Nusa Tenggara, Maluku juga dapat memanfaatkan PLTS untuk memenuhi kebutuhan listriknya. Hal tersebut sangat tepat karena kedua wilayah tersebut mempunyai potensi intensitas radiasi matahari yang tinggi sekitar 5,7 kWh per m2, kondisi geografis yang terdiri dari beberapa kepulauan yang menyebabkan penduduknya tersebar, pasokan listrik terbatas, adanya kebijakan pemerintah daerah untuk memprioritaskan pembangunan pembangkit listrik skala kecil yang memanfaatkan sumber energi setempat dan terbarukan, serta mengembangkan tenaga listrik yang modular yang dapat diinstalasi di lokasi yang sulit tanpa membutuhkan jaringan transmisi dan distribusi.

Pada Tabel 1 terlihat bahwa apabila biaya investasi PLTS tetap sebesar 1.650 US $\$ / \mathrm{kW}$, pada tahun 2010, dan 2016 sebesar 1.700 US\$/kW maka PLTS selain dapat diinstalasi di Maluku dan Nusa Tenggara juga dapat diinstalasi di pedalaman Kalimantan, relatif lebih murah dan efisien bila menggunakana PLTD.

PLTS sangat berpotensi untuk diterapkan di Maluku karena Maluku mempunyai kondisi geografi yang terdiri dari kepulauan. Hal tersebut yang menyebabkan produksi listrik PLTS di Maluku meningkat dengan laju pertumbuhan rata-rata $6,24 \%$ per tahun, yaitu dari 0,09 PJ pada tahun 2015 menjadi 0,32 PJ 
pada tahun 2030. Nusa Tenggara Barat dan Nusa Tenggara Timur menggunakan PLTD untuk memenuhi beban puncaknya, tetapi PLTD di wilayah ini umumnya sudah tua sehingga produksi listriknya semakin menurun, sehingga pada tahun 2010, PLTS sudah mulai berperan di kedua wilayah Nusa Tenggara dengan total produksi listrik sebesar 0,03 PJ (kasus dasar dan PVCOST) dan meningkat menjadi 0,08 PJ (kasus dasar) dan 0,52 PJ (PVCOST) pada tahun 2030. PLTS di wilayah ini tidak mampu bersaing dengan PLTA dan PLTU Batubara 7 MW dan hanya menggantikan kapasitas PLTD yang semakin berkurang.

Hampir 96\% dari kapasitas terpasang PLTD berada di luar Jawa, tetapi sebagian besar PLTD tersebut telah berusia cukup tua, misalnya PLTD di Kalimantan Timur dan Riau telah beroperasi selama 15 sampai 25 tahun yang menyebabkan produksi listriknya semakin menurun, kondisi ini merupakan salah satu faktor bagi meningkatnya peran PLTS.

Di wilayah Kalimantan, dalam rangka memeratakan pembangunan, pemerintah daerah Kalimantan telah melakukan optimasi penyediaan listrik untuk memenuhi kebutuhan listrik di daerah terpencil dan terisolir dengan memanfaatkan PLTS melalui dana APBN dan APBD. PLTS di Kalimantan dapat menunjang PLTD yang digunakan untuk memenuhi beban puncak, khusus di Kalimantan Barat, pemanfaatan PLTS akan bersaing dengan PLTA. Produksi listrik PLTS di Kalimantan pada tahun 2020 adalah 1,01 PJ (kasus dasar) dan 3,32 PJ (PVCOST) dan pada tahun 2030 meningkat menjadi 4,88 PJ (kasus dasar) dan 12,68 PJ (PVCOST). Berlainan dengan Kalimantan Barat, PLTS di Kalimantan Timur akan dapat bersaing dengan PLTU Batubara 100 MW dengan catatan setelah biaya investasi PLTS lebih rendah dari 1.650 US\$/kW, sedangkan di Kalimantan Tengah PLTS mulai berperan pada tahun 2030.

Seiring dengan meningkatnya kebutuhan listrik di Sumatra dan umur PLTD yang terpasang sudah mencapai lebih dari 15 tahun, memungkinkan pada tahun 2025 wilayah Sumatra juga memerlukan pemanfaatan PLTS untuk menunjang pasokan listrik di wilayah tersebut, khususnya di daerah terpencil dan di daerah yang terisolasi. Produksi listrik dari PLTS pada tahun 2025 sebesar sebesar 17,58 PJ (kasus dasar), sedangkan pada PVCOST, pada tahun 2020 PLTS sudah mulai berperan dengan produksi listrik sebesar 0,67 PJ dan meningkat menjadi 128,65 PJ pada tahun 2030. Meningkatnya peran PLTS di Sumatra ditunjang dari umur PLTD di wilayah ini sudah tua, serta adanya rencana strategis pemerintah daerah untuk memenuhi kebutuhan listrik dengan memanfaatkan sumber energi setempat seperti mini/mikrohidro dan energi surya sejak tahun 2005.

Seperti halnya di wilayah Sumatra, di Jawa pertumbuhan konsumsi tenaga listrik rata-rata dari tahun 1999 sampai dengan tahun 2003 mencapai $7 \%$ per tahun, apabila pertumbuhan konsumsi tenaga listrik rata-rata diasumsikan tetap, pada tahun 2030 Jawa diperkirakan membutuhkan PLTS sebesar 12,16 GW. Hal tersebut dipicu dengan terbatasnya pasokan gas bumi, BBM, dan batubara pada pembangkit listrik, mengingat gas bumi lebih diutamakan untuk memenuhi kebutuhan bahan baku dan bahan bakar di sektor industri, sedangkan BBM lebih diutamakan untuk memenuhi kebutuhan bahan bakar di sektor transportasi. Selain itu, untuk meningkatkan pemakaian batubara harus ditunjang pengembangan pelabuhan penerima batubara di Jawa. Pengembangan pelabuhan penerima batubara di Jawa memerlukan lahan sangat luas dengan biaya investasi yang relatif besar. Akan tetapi pemanfaatan PLTS sebesar 12,16 GW pada kasus dasar dan 46,65 GW pada kasus PVCOST di Jawa dan 16,85 GW pada kasus PVCOST di Sumatra dapat dikatakan tidak rasional mengingat masih ada sumber energi setempat yang dapat dimanfaatkan seperti mini/mikrohidro dan panas bumi yang belum dimanfaatkan secara optimal.

\section{Kesimpulan}

Dalam Strategi teknologi yang terkait dengan Peraturan Menteri ESDM No. 19 Tahun 2016 tentang Pemberlian Tenaga Listrik dari Pembangkit LIstrik Tenaga Surya Fotovoltaik oleh PT. PLN, berdasarkan hasil keluaran model MARKAL, Potensi Energi Surya Indonesia mempunyai intensitas radiasi yang berpotensi untuk membangkitkan energi listrik, dengan rata-rata daya radiasi matahari di Indonesia sebesar 1000 Watt $/ \mathrm{m} 2$. Dan dari analisis Pemanfaatan PLTS per Wilayah menunjukkan bahwa apabila biaya investasi PLTS tetap sebesar 1.650 US\$/kW, pada tahun 2010, dan 2017 sebesar 1.700 US\$/kW maka PLTS selain dapat diinstalasi di Maluku dan Nusa Tenggara juga dapat diinstalasi di pedalaman Kalimantan, relatif lebih murah dan efisien bila 
menggunakana PLTD. Eqivalensi Secara umum biaya pembangkitan PLTS lebih mahal dibandingkan dengan biaya pembangkitan pembangkit listrik tenaga fosil, pembangkit listrik tenaga air, minihidro, dan panas bumi. Tetapi seiring dengan adanya penelitian dari Amerika yang menyatakan bahwa biaya investasi PLTS di masa datang akan menurun, sehingga dengan dihapuskannya subsidi Bahan Bakar Minyak (BBM) secara bertahap dimungkinkan PLTS dapat dipertimbangkan sebagai pembangkit listrik alternatif.

\section{Daftar Pustaka}

- Peraturan Menteri ESDM No. 19 Tahun 2016 tentang Pemberlian Tenaga Listrik dari Pembangkit LIstrik Tenaga Surya Fotovoltaik oleh PT. PLN.

- $\quad$ "IEA-ETSAP". Retrieved 29

September 2014.

- $\quad$ Jump up^ MARKAL vs TIMES ieaetsap.org

- $\quad$ BPPT. Out put model MARKAL, 2015

- Fitriana, I., Evaluation of Socio-Economic Aspects Of Solar Home System Programme Implementation In Indonesia, 2003 